\title{
Future scenarios of fish supply and demand for food and nutrition security in Bangladesh: An analysis with the AsiaFish model
}

Nhuong Tran ${ }^{1 *}$, U-Primo Rodriguez ${ }^{2}$, Chin Yee Chan ${ }^{1}$, Yee Mon Aung ${ }^{1}$, Long Chu Abu Hayat Md.Saiful Islam ${ }^{4}$ Benoy Kumar Barman ${ }^{5}$, Michael John Phillips ${ }^{1}$

${ }^{1}$ WorldFish, Jalan Batu Maung, Batu Maung, Penang, Malaysia

${ }^{2}$ Department of Economics, University of the Philippines Los Baños, Philippines

${ }^{3}$ Crawford School of Public Policy, the Australian National University, Canberra, Australia

${ }^{4}$ Department of Agricultural Economics, Bangladesh Agricultural University (BAU), Mymensingh, Bangladesh

${ }^{4}$ WorldFish Bangladesh, House no: 88, 2B Rd No. 4, Dhaka, Bangladesh

*Corresponding author: Nhuong Tran, Email: N.Tran@cgiar.org

Postal address: WorldFish, Jalan Batu Maung, Batu Maung, 11960 Bayan Lepas, Penang, Malaysia

\section{ABSTRACT}

Bangladesh has made significant progress in social and economic development in recent years, but micronutrient deficiencies and poor dietary diversity remain a significant challenge. This paper developed eight scenarios to explore fish supplydemand futures in Bangladesh using the AsiaFish model, with special emphasis on the role of fish in micronutrient supply to address the nation's malnutrition and nutrition security challenges. A business-as-usual (BAU) scenario followed historical trends for exogenous variables used in the model. The seven alternative scenarios explored were: the implications of increase productivity of farmed tilapia, pangasius and rohu 
carp (AS1); productivity changes in hilsa production (AS2); improvements in the quality of feeds (AS3); reduction in the price of plant-based feeds (AS4); disease outbreak in farmed shrimps and prawns (AS5); and climate change impact (AS6) and stagnant capture fisheries (AS7). The BAU scenario indicates that aquaculture growth will be a prominent contribution to increasing total fish supply and demand and fish exports to 2040. Apart from the scenarios that are favourable to aquaculture sector development, other alternative scenarios highlighted the lower growth rate of capture fisheries and aquaculture compared to BAU, resulting in declining in per capita fish consumption, fish exports and nutrient supply from fish as a consequence. Increased availability of aquaculture fish can slightly compensate for the lower growth of capture fisheries in term of their nutrition quality and dietary diversity, particularly for poor consumers. Policies towards sustaining fisheries and a nutrition-sensitive approach to aquaculture is recommended as both capture fisheries and aquaculture are essential for sustaining healthy and nutritious diets in Bangladesh.

Keywords: AsiaFish model, Scenarios, Supply-demand, Micronutrient, Bangladesh 


\section{Introduction}

Fisheries and aquaculture are an integral part of agri-food systems in many developing countries, supplying fish and other aquatic foods, a more environmentally sustainable animal-source food (Hallstrom et al., 2019) to meet the national and global goal of food and nutrition security (Willett et al., 2019). Over the last four decades, fisheries and aquaculture systems in developing countries have changed profoundly, driven by the proliferation of aquaculture and faltering capture fisheries (Belton and Thilsted, 2014; Tran et al., 2020). Growth of global aquaculture has made a positive contribution to global food and nutrition security, boosting world fish supplies, mitigating fish output reduction from capture fisheries to meet increasing demand for fish. Using the AsiaFish model, in this paper, we explore future scenarios for fish supply and demand and its implications for food and nutrition security in Bangladesh, a lower-middle income country facing multiple challenges to meet the nation goal of reducing malnutrition and micronutrient deficiencies.

The fishery sector in Bangladesh plays an increasingly significant role in the national economy through foreign exchange earnings, animal-source protein and food supply, food security, employment opportunities and supporting overall socioeconomic development and sustainable livelihoods (Islam, et al., 2018; Rashid and Zhang, 2019). In 2018, Bangladesh ranked one of the largest fish producers in the world, 3rd after China and India in the inland capture fishery production, 5th in term of world aquaculture production after China, India, Indonesia and Vietnam (FAO 2020) and become self-sufficient in fish production (FRSS, 2018). The sector contributed $3.50 \%$ of national gross domestic product (GDP), more than one-fourth $(25.72 \%)$ to the agricultural GDP and 3\% of Bangladesh's total foreign exchange earnings in 2017 (FRSS, 2018). In terms of employment, the sector created full-time and part-time jobs 
for $12 \%$ of the Bangladesh population of 165 million people (FRSS, 2018). Fish is one of the most important foods in the Bangladeshi diet, contributing $60 \%$ of total animalsource foods while per capita fish consumption in Bangladesh has reached 62.58 grams/day in 2017 (BBS, 2018).

There are three sources of domestic fish supply in Bangladesh, namely inland culture, inland capture, and marine capture. The total fish production in Bangladesh has increased six-fold and its steadily increasing trend has been maintained over the past 36 years (total output increased from 754,000 metric tons (MT) in 1983-84 to 4,384,000 MT in 2018-19). The majority of fish supply in Bangladesh comes from inland culture and capture fisheries (accounting for $84.53 \%$ of total production) (FRSS, 2020), of which, aquaculture has been playing a crucial role to boost inland fisheries production to meet the increasing fish demand of Bangladesh population (Finegold, 2009). Aquaculture in Bangladesh is practiced in freshwater and brackish water environment with diverse production systems ranging from extensive, improved extensive, semi-intensive to intensive aquaculture. Inland aquaculture in freshwater is mainly comprised of fish farming of Indian major carps (Rohu, Mrigal, Catla), exotic and other carps (Silver carp, Bighead carp, Grass carp, and Common carp), pangasius, and tilapia. Coastal aquaculture mainly includes brackish water shrimp farming in ghers. The contribution of aquaculture in Bangladesh's total fish production has been remarkably increased from $15.53 \%$ in $1983-84$ to $56.76 \%$ in $2018-19$ (FRSS, 2020).

Landings from inland capture and marine fisheries in Bangladesh has been increasing at average growth rates of $1.58 \%$ and $0.80 \%$ over the $1983 / 1984$ $2018 / 2019$ period, respectively, contributing $28.19 \%(1,235,000$ MT) and $15.05 \%$ (660,000 MT) to total fish production in 2018-19 (FRSS, 2020). Of capture fish species, 
Hilsa, the national fish of Bangladesh accounted for the highest share $(12.15 \%)$ in the country's total fish production in 2018-19 (FRSS, 2020). Although annual total hilsa catch has sharply declined in 2002-03, its production trends have been gradually reversed, growing at the rate of $3.5 \%$ per year from $2005-06$ to $2014-15$ thanks to the government's efforts and donor funded project interventions, including banning on catching brood fish and fries, implementation of jatka conservation program, Hilsa fisheries management action plan (HFMAP) and hilsa spawning protection activities and management of fish sanctuary (FRSS, 2020). The majority of Bangladesh's total catch fish of Hilsa (65\% of total Hilsa fish production) currently originated from the marine capture resources (DOF, 2017).

While fish production and consumption in Bangladesh have been increased in recent years, malnutrition and high levels of micronutrient deficiencies and moderate or severe food insecurity are still significant development challenges. One in every three children under five years in Bangladesh are estimated to be stunted and underweight, one in every five adult women are undernourished, most children under fifteen years live with higher level of nutritional deficiencies and millions of people are suffering micronutrient deficiencies (NIPORT et al., 2016; Fiedler et al., 2014). Inadequate Vitamin A, iron and zinc intake is a major public health problem (Harika et al., 2017).

Fish and other aquatic products are defined as 'irreplaceable' animal-source foods due to their intrinsic nutrient contents, contributing to food and nutrition security in many developing countries (Bogard et al., 2015). In Bangladesh, among animalsource foods, fish is by far the cheapest source and the most important multiple nutrient rich food in the diet. It provides a wide range of micronutrients, protein and fatty acids essential for human brain, bone and nervous system development, growth, 
cognition and disease prevention (Tacon and Metian, 2013; Nestel et al., 2015; Ezzati and Riboli, 2013). Several species from inland capture, typically consumed whole with head and bones, are rich in essential fatty acids and could contribute more than $25 \%$ of the recommended nutrient intakes including iron, zinc, calcium, iodine, vitamin $A$ and vitamin B12, for pregnant and lactating women and infants.

The success and rapid growth of aquaculture in Bangladesh linked to a "blue revolution' can fulfill the demand of the growing population (Rashid and Zhang, 2019). However, several studies (Bogard et al., 2015; 2017) highlight that substantial increases in farm-fish consumption has not sufficiently compensated for the nutrient supply from wild fish due to the lower nutritional quality of farmed-fish species compared to non-farmed species. A range of approaches and interventions from both supply and demand side are needed to sustain and enhance capture fisheries and aquaculture contributions to food and nutrition security goals in Bangladesh (Belton et al., 2014). Using a partial economic equilibrium AsiaFish model, this paper examines future scenarios for fish supply and demand in Bangladesh to 2040 and draw implications on the role of fish in nutrient supply to address the nation's malnutrition, food and nutrition security challenges.

\section{Methodology}

\subsection{Overview of the modelling approach}

Multiple modelling approaches have been proposed to project supply-demand equilibrium in agriculture and fishery. Some models provide projections at an aggregate level (e.g., global or multi-country scales) where fisheries are incorporated as an agricultural sub-sector. They include the International Model for Policy Analysis of Agricultural Commodities and Trade (IMPACT model) (Rosegrant and Team, 2012),

the AGLINK-COSIMO model (FAO, 2016), the Common Agricultural Policy 
Regionalized Impact model (CAPRI model), and the Global Biosphere Management Model (GLOBIOM model) (Chang et al., 2018; Latka et al., 2018). Other models provided projections at a higher disaggregation level and focused on fishery sectors at a national scale, e.g., the AsiaFish model developed by Dey et al. (2005 and 2016) and the primal multi-species-multi-sector model proposed by Tran et al. (2017 and 2019). Both groups of modelling approaches have been applied in many studies to analyze the trend and fundamental dynamics of fishery sectors around the world (Rodriguez et al., 2019; 2018; 2011; Henriksson et al., 2017; Chan et al., 2017; 2019; Rosegrant et al., 2017; OECD/FAO, 2017; Phillips et al., 2015; World Bank, 2013; Garcia et al., 2013; Brooks and Philips, 2012; Weeratunge et.al., 2010; Delgado et al., 2003).

This paper applied the AsiaFish model to the fishery sector of Bangladesh. This modelling approach features partial supply-demand equilibrium for each fish species or group of species. The total demand for fish includes fish consumed by domestic households (consumption), fish used by firms (intermediate inputs), and fish consumed by foreign countries (exports). Fish supply sources include domestic production and imports. The demand for domestic consumption is formalized using the Quadratic Almost Ideal Demand System (QUAIDS) (Edgerton, 1997; Blundell et al., 1993; Banks et al., 1997). The demand function for intermediate inputs and the supply function of domestic producers are derived via the normalized profit function approach (Dey et al., 2005). The formalization of international trade assumes the Armington CES specification (Armington, 1969), differentiating fish species and species groups.

The nutrition module of the model identified the protein and energy content of fish groups. The model also estimated the micronutrients and mineral content of fish 
species, as motivated Fiedler et al. (2016), who showed evidence for high levels of nutritional deficiencies among children under the age of 15 as well as among nonpregnant and non-lactating women aged 15 to 49 years. Five micronutrients and mineral contents considered in the model were vitamin A, iodine, zinc, iron, and calcium.

\subsection{Data and data sources}

Calibrating the AsiaFish model requires a dispensable dataset. This dataset includes disaggregated fish quantity and prices, quantities and prices of inputs for producing fish, and rural and urban population and income. We managed to retrieve some of these data from various sources, including the Department of Fisheries and its publications, FAO (2014), HIES, publications of the WorldFish Center, survey data from Agro Solution, and Asian Development Bank (ADB, 2014). Other information is not available, such as the quantity of fish that firms purchase to produce processed fish for human consumption (IDH). To overcome this challenge, we computed IDH as a net residual of domestic production plus import net consumption, export and intermediate inputs.

Table 1 summarizes the data for seven key fish groups in Bangladesh. The seven fish groups were Indian major carp, exotic carp, tilapia, pangasius, shrimps and prawns, hilsa, and other fish. Production of the specified species groups can be produced from four environments (marine capture, inland capture, inland culture, and brackish water culture). The table also distinguished rural and urban households. For all species, demands for and supplies are equal. Parameters of the model were drawn from the work by Ahmed et al. (2004).

Table 2 reports the proportion of edible parts to the total body weight of different fish groups. The coefficients for the fish groups represent the median of nutritional 
coefficients of fish species (e.g., Indian major carp: rohu, mrigal, catla) and fish sizes (e.g., small and regular sized fish for hilsa) provided in Bogard et al. (2016). The only exceptions are the vitamin A coefficients for exotic carp and shrimps and prawns obtained from the United States Department of Agriculture (undated) and Belton et al. (2014). Annex A described in detail the nutrition coefficients and proportions of edible parts. An important limitation of the nutrition module is the omission of processed fish. However, the impact of this shortcoming is not likely to be large because processed fish consumption is only about $2 \%$ of total fish consumption. Another limitation is that the remaining non-edible parts of the fish, that are highly nutritious parts, are lost from the model. Very little is known about the amount and fate of these "waste" nutrients and how they can be better utilized for human consumption (e.g., in fish-based products).

\subsection{Scenario analysis}

The model was calibrated to project the dynamics of the fishery sector in Bangladesh until 2040. The business-as-usual (BAU) scenario assumes historical growth rates for exogenous variables, including prices of food items, import prices of fish and fishmeal, export prices of fish, wage rate, fuel prices, prices of non-fish feeds and fish seeds, regional population, and regional incomes. These historical growth rates were estimated from previous studies and several data sources such as ADB (2020 and 2014), BBS (2020, 2018, 2015 and 2013), FAO (2020 and 2014), World Bank (2021) and the United Nations (2014).

A participatory workshop was organized in WorldFish Centre headquarters in Penang to formalize alternative scenarios. Workshop participants were international and Bangladeshi experts, including representatives from public and private sectors, industry associations, research institutions, national and international non-profit 
organizations in Bangladesh, and academia. The workshop participants have collectively constructed seven alternative scenarios (ASs) as follow:

- Scenario 1 (AS1) focuses on the possibility of increasing the productivity of farmed tilapia, pangasius and rohu carp. It assumes a $25 \%$ increase in productivity for these species in 2040. In this scenario, the productivity improvement was approximated based on existing or planned government policies and initiatives, e.g., tilapia and rohu production was expected to benefit from the Integrated Agricultural Productivity and National Agricultural Technology projects and CGIAR research program on agri-food fish systems to accelerate innovation, dissemination, and adoption of improved fish strains and best aquaculture management practices by aquaculture farmers in Bangladesh.

- Scenario 2 (AS2) focuses on the hilsa species, a traditional wild-caught species in Bangladesh. This scenario assumes a $25 \%$ increase in the output of hilsa. This scenario reflects the possible benefit of regulations designed to conserve fish stocks.

- Scenario 3 (AS3) assumes improvements in the quality of feeds where fishmeal output per unit of fish inputs would increase by $25 \%$.

- Scenario 4 (AS4) assumes a $25 \%$ decline in the price of plant-based feeds for aquaculture. Feed-related scenarios (AS3 and AS4) were motivated by the literature assessment undertaken by Bene et al. (2016), which concluded that it would be possible to meet future demands for fish with sustainable management of fishing resources and lower reliance on fishmeal and fish oil.

- Scenario 5 (AS5) focuses on the impact of possible disease outbreaks in aquaculture. This scenario assumes that infectious diseases would reduce the output of shrimp and prawn farms by $25 \%$ in 2025 . However, this negative impact 
is considered short-term, and the industry would recover to pre-outbreak levels by 2030.

- Scenario 6 (AS6) examines the possible negative impacts of climate change on fishing. Bangladesh is one of the most vulnerable countries to climate change (Mojid, 2020), and many previous studies have concluded that climate change would have significant impacts on the Bangladesh fish sector (e.g., Ahmed and Diana, 2015; Chand, 2015; and Bene et al., 2016). Thus, this scenario assumes a productivity decline of $10 \%$ and $25 \%$ for aquaculture and capture fisheries, respectively.

- Scenario 7 (AS7) investigates the impact of possible stagnation in capture fisheries. This scenario assumes the output of capture fisheries would remain unchanged from 2030 due to existing unsustainable fishing practices and the negative impacts of climate change. 
Table 1 Balance sheet for the Bangladesh AsiaFish model, 2010

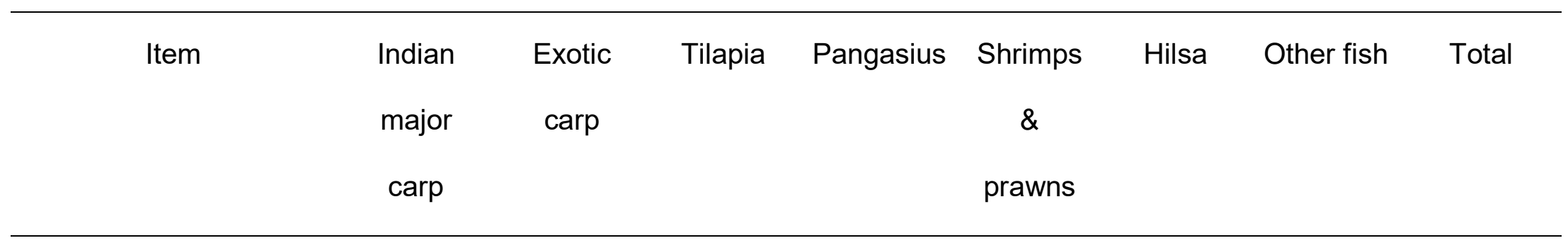

Quantity (tons)

Total Production

Marine capture

\begin{tabular}{|c|c|c|c|c|c|c|c|}
\hline - & - & - & - & 56,989 & 225,325 & 264,019 & 546,333 \\
\hline 92,009 & 36,196 & 252 & 535 & 55,132 & 114,520 & 755,941 & $1,054,585$ \\
\hline 688,770 & 221,863 & 104,716 & 156,375 & 4,059 & - & 101,706 & $1,277,489$ \\
\hline - & - & - & - & 123,280 & - & 60,000 & 183,280 \\
\hline - & - & - & - & 144 & - & 7,045 & 7,18 \\
\hline 19 & - & 21 & - & 45,324 & 8,690 & 38,833 & 92,8 \\
\hline
\end{tabular}




\begin{tabular}{|c|c|c|c|c|c|c|c|c|}
\hline Rural Consumption & 562,381 & 213,195 & 79,707 & 125,487 & 141,216 & 186,054 & 611,278 & $1,919,318$ \\
\hline Urban Consumption & 210,327 & 42,202 & 24,158 & 29,805 & 51,060 & 141,685 & 176,600 & 675,838 \\
\hline \multicolumn{9}{|l|}{ Intermediate Demand } \\
\hline Process & 8,052 & 2,661 & 1,082 & 1,618 & 2,004 & 3,415 & 8,210 & 27,043 \\
\hline \multirow{2}{*}{ Fish for fishmeal } & & & & & & & 353,791 & 353,791 \\
\hline & \multicolumn{8}{|c|}{ Value (million taka) a } \\
\hline \multicolumn{9}{|l|}{ Total Production } \\
\hline Marine capture & - & - & - & - & 12,933 & 55,331 & 22,398 & 90,662 \\
\hline Inland capture & 11,454 & 3,383 & 26 & 52 & 12,512 & 28,121 & 64,130 & 119,677 \\
\hline Inland culture & 85,743 & 20,738 & 10,618 & 15,110 & 921 & - & 8,628 & 141,758 \\
\hline Brackishwater culture & - & - & - & - & 27,977 & - & 5,090 & 33,067 \\
\hline Import & - & - & - & - & 93 & - & 562 & 655 \\
\hline
\end{tabular}




\begin{tabular}{|c|c|c|c|c|c|c|c|c|}
\hline Export & 4 & - & 4 & - & 28,084 & 3,275 & 7,456 & 38,821 \\
\hline Rural Consumption & 67,014 & 19,471 & 7,793 & 11,685 & 17,446 & 41,122 & 64,735 & 229,265 \\
\hline Urban Consumption & 29,177 & 4,401 & 2,738 & 3,321 & 8,634 & 38,229 & 23,453 & 109,953 \\
\hline \multicolumn{9}{|l|}{ Intermediate Demand } \\
\hline Process & 1,002 & 249 & 110 & 156 & 272 & 827 & 919 & 3,535 \\
\hline Fish for fishmeal & - & - & - & - & - & - & 4,245 & 4,245 \\
\hline
\end{tabular}

a The ADB (2014) indicates an exchange rate of 65.7 taka/US\$ in 2010 
Table 2 Nutrition coefficients and edible proportions of fish

\begin{tabular}{|c|c|c|c|c|c|c|c|c|}
\hline \multirow[b]{2}{*}{ Fish group } & \multicolumn{2}{|c|}{ Nutrients } & \multicolumn{5}{|c|}{ Micronutrients \& minerals } & \multirow{2}{*}{$\begin{array}{l}\text { Proportion of } \\
\text { edible parts }\end{array}$} \\
\hline & Energy ${ }^{a}$ & Protein ${ }^{b}$ & Vitamin A $\mathrm{c}$ & Iron d & Zinc $^{d}$ & lodine d & Calcium ${ }^{d}$ & \\
\hline Indian major carp & 3,630 & 182 & 150.00 & 9.05 & 10.50 & 180.00 & 2100 & 0.79 \\
\hline Exotic carp & 4,080 & 168 & 90.00 & 11.00 & 18.00 & 255.00 & 1620 & 0.81 \\
\hline Tilapia & 4,010 & 193 & 155.00 & 13.50 & 13.00 & 110.00 & 1075 & 0.80 \\
\hline Pangas & 6,425 & 173 & 215.00 & 16.95 & 8.75 & 170.00 & 338 & 0.80 \\
\hline Shrimps and prawns & 3,485 & 167 & 540.00 & 78.50 & 23.00 & 730.00 & 8750 & 0.40 \\
\hline Hilsa & 8,190 & 177 & 170.00 & 22.00 & 15.00 & 355.00 & 3600 & 0.87 \\
\hline Other fish & 3,840 & 170 & 760.00 & 18.00 & 17.50 & 185.00 & 6880 & 0.85 \\
\hline
\end{tabular}

Notes: ${ }^{a}$ in kilojoules $/ \mathrm{kg}$ of edible parts; ${ }^{\mathrm{b}}$ in grams $/ \mathrm{kg}$ of edible parts; ${ }^{\mathrm{c}}$ in micrograms $/ \mathrm{kg}$ of edible parts; ${ }^{\mathrm{d}}$ in milligrams $/ \mathrm{kg}$ of edible parts; e 0.79 means that $79 \%$ of fish parts are edible. 


\section{Results}

\subsection{Business-as-usual (BAU) scenario}

Our projection results show that under the BAU scenario, fish supply in Bangladesh is projected to be strong and rise almost to double by 2040 (Table 3). While capture fisheries production is likely to expand at $1.4 \%$ per year between 2020 and 2040, aquaculture production is projected to increase from $2,583.85$ thousand tons in 2020 to $5,464.32$ thousand tons in 2040 (projected average growth rate at 3.8\% per year) (Fig. 1). With sluggish growth of capture fisheries and relatively higher growth of aquaculture, per capita fish consumption at the national level is expected to gradually increase from $25.16 \mathrm{~kg}$ in 2020 to about $37.1 \mathrm{~kg}$ in 2040 , where aquaculture is likely to be the major contributor to the total consumption. Increase in total fish consumption are mainly attributable to the relatively rapid expansion of per capita fish consumption in rural areas with a 2.19\% average annual growth rate between 2020 and 2040 (Table 3). As presented in Table 3, fish exports and imports (fish trade) are expected to increase annually by $4.43 \%$ and $4.65 \%$, respectively, over the projection period, with both exports and imports being larger by 2040 ( 180.19 thousand tons and 157.10 thousand tons, respectively) than in 2020. Average producer and consumer prices of fish are projected to increase in 2040 compared to 2020 with likely implications for the poor and vulnerable consumers (Table $3)$.

As described in Fig. 1, production of all aquaculture species groups is expected to increase between 2020 and 2040. In terms of production share of each fish group, IMC is expected to remain the largest source of farmed fish supply in Bangladesh followed by Tilapia and Pangasius by 2040. The production of IMC is projected to be almost double 
in $2040(1,584.30$ thousand tons) compared to 2020 . Tilapia (from 369.80 thousand tons in 2020 to $1,215.99$ thousand tons in 2040) and Pangasius (from 388.67 thousand tons in 2020 to $1,048.69$ thousand tons in 2040) will also likely experience prominent increases in their contribution to overall fish supply in Bangladesh. Similarly, production of the species groups of exotic carp, shrimps and prawns, and other fish species) are projected to increase by between 1.33 and 1.71 times between 2020 and 2040. In terms of potential nutrition contribution from fish, under the BAU scenario, the key nutrient supply from fish including vitamin A, iron, iodine, zinc, calcium, protein and energy in 2040 are projected to increase by between 1.22 and 1.48 times compared to those in 2020 . These results reflect the different nutrients contribution from fish as fish is one of the main contributors to the food and nutrition security due to their increasing nutrients supply by 2040 (Fig. 2).

\subsection{Alternative scenarios for growth}

Table 4 summarizes the results for the alternative scenarios (ASs) in comparison to the key outcomes associated with the BAU scenario. Apart from demonstrating the potential impacts of interventions or policies on fisheries sector in Bangladesh, the ASs projections also provide a sense of the sensitivity of fish supply, demand, trade, prices and key nutrients supply from fish to changes in exogenous variables discussed in the method section (e.g., prices of food items, import prices of fish and fishmeal, export prices of fish, wage rate, fuel prices, prices of non-fish feeds and fish seeds, regional population, and regional incomes). 


\subsubsection{Increase productivity of farmed tilapia, pangasius and rohu carp (AS1)}

Under the assumption of increase productivity of farmed tilapia, pangasius and rohu carp (AS1), the projection results show that both farmed tilapia, pangasius and IMC outputs would be substantially higher $(13.7 \%, 69.0 \%$ and $21.4 \%$, respectively) compared to the BAU scenario by 2040 (Table 4 and Fig.3). The positive impacts of the productivity improvements are also reflected in the increases in the total aquaculture output $(18.2 \%)$ and overall fish production (12.3\%) compared to BAU in 2040 as presented in Fig. 3 . Furthermore, higher productivity tends to cause lower consumer prices of fish, and brings additional benefits to the economy in the form of higher exports, lower imports and increase in per capita fish consumption as shown in Fig. 3. Per capita fish consumption is projected to be $13.4 \%$ higher than that in the BAU scenario by 2040 . While the fish exports are expected to exceed BAU levels by $7.3 \%$ in 2040 , fish imports are projected to reduce by $7.6 \%$ than BAU levels by 2040 . Overall, due to higher fish availability, consumer and producer prices of fish are decline $(-5.5 \%$ and $-4.4 \%$, respectively) under AS1 compared to BAU. With regards to the potential nutrients contribution from fish presented in Fig. 4, it shows that all nutrients contribution from fish are projected to increase within the range of $3.2 \%$ to $16.6 \%$ by 2040 . The results also suggest significant nutritional benefits particularly increase in micronutrients (e.g. energy, iron, zinc, vitamin A and protein) contribution from fish under this scenario.

\subsubsection{Productivity changes in hilsa production (AS2)}

As shown in Table 4, the impacts from productivity improvements in hilsa (AS2) are very similar to AS1 in the sense that it leads to lower consumer prices and higher exports. Unlike AS1, overall fish production and aquaculture fish output is lower but the total output 
from capture fisheries in 2040 is projected to be $12.2 \%$ higher than the BAU scenario because hilsa only comes from this source (Fig.3). However, this increase cannot offset the decline in aquaculture output resulting overall decline in total fish output $(-1.6 \%)$ and per capita fish consumption $(-1.4 \%)$ relative to the BAU scenario by 2040 . Fish exports are projected to be $18.9 \%$ higher than the BAU in 2040 . Most of this increase is likely to come from the increase in hilsa fish supply because hilsa is one of the major fish export items in Bangladesh.

Following the lower aquaculture fish production, overall fish output and declining in imports, per capita fish consumption is also projected to be $-1.4 \%$ lower under AS 2 than in the BAU (Table 4 and Fig. 3). Weighted average of consumer and producer prices of fish are projected to be $-10.4 \%$ and $-7.7 \%$ lower compared to the BAU in 2040 . Under the AS2, there are also mixed results on the direction of the changes for the nutrition coefficients, indicating that Zinc and Protein contributions from fish over the simulation period are expected to experience modest decline $(-1.9 \%$ and $-0.5 \%$, respectively, compared to BAU) (Table 4 and Fig.4). In terms of disaggregated projections for aquaculture and capture species under AS2, except pangasius from both capture and aquaculture production and hilsa from capture production, all species production is projected to decline resulting overall fish output decline compared to BAU scenario (Table 4).

\subsubsection{Improvements in the quality of feeds (AS3)}

AS3 which simulated through lower fish inputs per unit of fishmeal output, also yields benefits to the sector. These scenario results presented in Table 4 and Fig. 3 show that total fish production which combines aquaculture and capture fisheries production would 
be slightly lower, with estimated 2040 production being only $-0.4 \%$ lower than BAU, but per capita fish consumption would increase by $1.6 \%$ as a result of decline in consumer prices. Simulation results also suggest favourable outcomes for exports because fish exports are expected to remain largely unaffected by AS3 relative to BAU. The potential nutrition contribution from fish would increase by between $1.3 \%$ and $4.6 \%$ compared to BAU (Table 4 and Fig.4). The most attributable nutrients contributions are observed for Vitamin A (4.6\%) and Calcium (4.2\%). These projections provide support for earlier assertions on the links between the demand for fish as feed and nutrition.

\subsubsection{Reduction in the price of plant-based feeds (AS4)}

With other assumptions remaining as in the BAU scenario, lower input costs (AS4) have favourable impacts on aquaculture and total fish production, exports, imports, consumption and potential nutrition contribution from fish. However, these outcomes are projected to increase at a lower rate within the range of $0.00 \%$ to $1.6 \%$ per year from 2020 to 2040 compared to that of the BAU scenario (Table 4, Fig. 3 and 4). On the other hand, capture fisheries production slightly declines, albeit small, also suggests eased pressure to harvest capture fish that will serve as inputs to aquaculture.

\subsubsection{Farmed shrimps and prawns' diseases (AS5)}

The scenario of diseases affecting shrimps and prawn's farming (AS5), is projected to have a widespread effect on the production of both the species as well as other aquaculture fish groups. Both shrimps and prawn (-7.5\%) fall below BAU projections, with an overall fish production decline of $0.8 \%$ from the aquaculture sector (Table 4 ). As presented in Table 4 and Fig.3, this also has "knock-on" effects on other key outcomes including decline in exports $(-0.6 \%)$, imports $(-1.4 \%)$, per capita fish consumption $(-0.4 \%)$, 
prices $(-0.1 \%)$ and nutrients contribution from fish (between- $0.3 \%$ and $-0.9 \%$ ) by 2040 compared to BAU. Most noticeable impacts under this scenario are the declines in aquaculture output and overall fish production. The decline in total fish production tends to reduce per capita fish consumption and fish exports. Lower consumption of fish in turn translates into lower supply of key nutrients from fish, especially zinc (Table 4 and Fig.4).

\subsubsection{Climate change impacts (AS6)}

Alternative scenario 6 (AS6) attempts to simulate the effects of climate change on key outcomes which are presented in Table 4 and Fig. 4. It is evident that climate change will negatively affect all fish species production across the aquaculture and capture fisheries. Total fish production including aquaculture and capture fisheries will decline by $-13.8 \%$ in 2040 relative to BAU (Table 4). This lower total production tends to raise consumer prices (14.9\% compared to BAU scenario), it is not surprising to observe declines in fish exports and per capita fish consumption by $-32.6 \%$ and $-14.4 \%$, respectively (Table 4 and Fig.3). The latter of these impacts causes significant reduction in all types of nutrients contribution from fish within the range of $-14.8 \%$ and $-18.8 \%$ across the nutrient's items under AS6 than BAU scenario (Table 4 and Fig.4). Most notably, if we compare all the alternative scenarios, this scenario (AS6) will have the worst impacts on different outcomes.

\subsubsection{Stagnant capture fisheries (AS7)}

The impacts of stagnation of capture fisheries scenario (AS7) show that the total output of capture fisheries will be about $-15 \%$ lower than BAU scenario by 2040 (Table 4 and Fig. 3) which result in aggregate fish output declines by about $-4.4 \%$ compared to BAU scenario. As presented in Table 4 and Fig.3, though aquaculture output increases 
$(0.7 \%)$ in this scenario, it is not enough to offset the decline of capture fisheries as a result aggregate fish output still declines compared to BAU scenario. The decline in fish supply causes the increase in fish price about $6 \%$ by 2040 . Furthermore, though both fish export and import are projected to negatively affected under this scenario (AS7) compared to BAU but exports would suffer most (fall by $-22 \%$ ). As a result of the decline in domestic supply, per capita fish consumption is also projected to decline by $-4.4 \%$ than BAU scenario. The latter of these impacts is consistent with a largely decline in contribution of various nutrients from fish, especially calcium (-13.5\%) and vitamin $A(-10.8 \%)$ compared to the BAU scenario in 2040 (Table 4 and Fig.4). Moreover, in terms of the impacts of AS7 on disaggregated aquaculture and capture fish production, results show heterogeneous impact trend (Table 4). Therefore, stagnation of capture fisheries scenario (AS7) has multiple implications on the projected welfare of the fish consumers and producers including fish production, consumption, and prices as well as the role of fish and other aquatic foods in key nutrient supply to contribute to the goal of reducing malnutrition and food and nutrition insecurity. 
Table 3 AsiaFish model BAU projected growth of fish production, international trade, per capita consumption, prices and potential nutrients from fish for Bangladesh

\begin{tabular}{|c|c|c|c|c|c|}
\hline & 2010 & 2020 & 2030 & 2040 & $\begin{array}{c}\text { Growth Rate (2020-2040) } \\
\%)\end{array}$ \\
\hline Domestic production & & & & ons & \\
\hline Aquaculture & 1460.769 & $2,583.85$ & 3646.625 & $5,464.32$ & 3.8 \\
\hline Indian Major carp & 688.77 & 870.81 & 1137.871 & $1,584.30$ & 3.0 \\
\hline Exotic carp & 221.863 & 429.94 & 549.425 & 733.75 & 2.7 \\
\hline Tilapia & 104.716 & 369.80 & 658.982 & $1,215.99$ & 6.1 \\
\hline Pangasius & 156.375 & 388.67 & 616.482 & $1,048.69$ & 5.1 \\
\hline Shrimps \& prawns & 127.339 & 125.02 & 169.555 & 203.00 & 2.5 \\
\hline Other Fish & 161.706 & 399.62 & 514.31 & 678.59 & 2.7 \\
\hline Capture & 1600.918 & $1,918.77$ & 2187.376 & $2,545.75$ & 1.4 \\
\hline Indian Major carp & 92.009 & 132.86 & 152.678 & 181.00 & 1.6 \\
\hline Exotic carp & 36.196 & 41.50 & 43.786 & 46.64 & 0.6 \\
\hline Tilapia & 0.252 & 1.71 & 3.312 & 6.64 & 7.0 \\
\hline
\end{tabular}




$\begin{array}{lccccc}\text { Pangasius } & 0.535 & 13.74 & 27.677 & 59.09 & 7.6 \\ \text { Shrimps \& prawns } & 112.121 & 115.52 & 123.637 & 126.03 & 0.4 \\ \text { Hilsa } & 339.845 & 548.00 & 601.013 & 662.33 & 1.0 \\ \text { Other Fish } & 1019.96 & 1,065.43 & 1235.274 & 1,464.03 & 1.6 \\ \text { Total a } & 3061.687 & 4,502.62 & 5834.001 & 8,010.07 & 2.9 \\ \text { International trade b } & & & & 000 \text { tons } & 4.43 \\ \text { Exports } & 96.86 & 75.72 & 186.784 & 180.19 & 4.65 \\ \text { Imports } & 11.093 & 63.25 & 154.011 & 157.10 & 2.19 \\ \text { Per capita consumption }{ }^{b} & & & & \text { kg/person/year } \\ \text { Rural } & 16.2 & 22.68 & 26.86 & 34.96 & 1.07 \\ \text { Urban } & 23.89 & 32.63 & 36.25 & 40.37 & 1.96 \\ \text { National } & 17.66 & 25.16 & 29.86 & 37.11 & 2.10 \\ \text { Prices } & & (\text { Taka/kg) (includes processed fish) } & \\ \text { Consumer } & 129.23 & 133.47 & 163.67 & 208.47 & 191.91 \\ \text { Producer } & 126.69 & 156.48 & \end{array}$


Potential nutrient supply from

fish ${ }^{\mathrm{c}}$

\begin{tabular}{lccccc} 
Vitamin A (micrograms) & 13.84 & 17.50 & 19.47 & 22.92 & 1.36 \\
Iron (milligrams) & 0.66 & 0.92 & 1.05 & 1.27 & 1.65 \\
lodine (milligrams) & 8.76 & 12.12 & 13.66 & 16.24 & 1.47 \\
Zinc (milligrams) & 0.55 & 0.76 & 0.88 & 1.07 & 1.69 \\
Calcium (milligrams) & 148.89 & 185.35 & 200.25 & 226.62 & 1.01 \\
Protein (grams) & 6.66 & 9.55 & 11.3 & 14.16 & 1.99 \\
Energy (kilojoules) & 173.18 & 256.54 & 299.57 & 371.57 & 1.87 \\
FMld & 353.791 & 490.373 & 620.092 & 774.521 & 2.312 \\
\hline
\end{tabular}

a Sum of the outputs of aquaculture and capture fisheries. ${ }^{b}$ Fresh and processed fish. ${ }^{c}$ These estimates exclude nutrients from the consumption of processed (mostly, dried) fish. However, processed fish consumption in Bangladesh in 2010 was only about $2 \%$ of total fish consumption. ${ }^{\mathrm{d}} \mathrm{FMI}=$ Fresh fish used as fishmeal inputs (000 tons) 
Table 4 The effects of alternative scenarios on key outcomes (\% deviation from the BAU scenario in 2040)

\begin{tabular}{|c|c|c|c|c|c|c|c|c|}
\hline \multirow{2}{*}{ Item } & \multirow{2}{*}{ Scenario BAU } & \multicolumn{7}{|c|}{ Percent deviation from BAU (2040) } \\
\hline & & AS1 & AS2 & AS3 & AS4 & AS5 & AS6 & AS7 \\
\hline \multicolumn{9}{|l|}{ Domestic production } \\
\hline Aquaculture & $5,464.3$ & 18.2 & -8.0 & -0.3 & 0.9 & -0.8 & -9.4 & 0.7 \\
\hline Indian Major carp & $1,584.3$ & 21.4 & -3.6 & -0.4 & 0.6 & 0.4 & -10.8 & 3.7 \\
\hline Exotic carp & 733.7 & -18.4 & -23.7 & 0.9 & 1.6 & -3.7 & -7.6 & -8.5 \\
\hline Tilapia & $1,216.0$ & 14.1 & -25.8 & 0.8 & 1.4 & -4.0 & -6.1 & -9.2 \\
\hline Pangasius & $1,048.7$ & 62.3 & 18.2 & -0.8 & -0.3 & 3.8 & -15.1 & 7.9 \\
\hline Shrimps \& prawns & 203.0 & -9.1 & -22.4 & 0.6 & 1.2 & -7.5 & -7.0 & 0.4 \\
\hline Other Fish & 678.6 & -2.1 & -5.3 & -2.8 & 1.3 & -0.1 & -6.0 & 10.0 \\
\hline Capture & $2,545.7$ & -0.5 & 12.2 & -0.6 & -0.2 & 0.4 & -23.2 & -15.2 \\
\hline Indian Major carp & 181.0 & -3.8 & -4.1 & -0.2 & -0.2 & 0.0 & -25.3 & -25.6 \\
\hline Exotic carp & 46.6 & -7.9 & -12.1 & 0.3 & 0.2 & -1.7 & -23.6 & -32.7 \\
\hline Tilapia & 6.6 & -19.8 & -19.0 & 0.4 & 0.2 & -2.6 & -24.6 & 230.9 \\
\hline Pangasius & 59.1 & -0.4 & 10.8 & -0.6 & -0.8 & 2.7 & -31.0 & 301.6 \\
\hline
\end{tabular}




\begin{tabular}{|c|c|c|c|c|c|c|c|c|}
\hline Shrimps \& prawns & 126.0 & -5.4 & -13.5 & 0.3 & 0.4 & -1.2 & -23.5 & -46.7 \\
\hline Hilsa & 662.3 & 2.4 & 56.0 & -1.0 & -0.6 & 1.9 & -26.2 & -14.3 \\
\hline Other Fish & $1,464.0$ & -0.6 & -2.4 & -0.6 & 0.0 & -0.1 & -21.2 & -25.0 \\
\hline Total & $8,010.1$ & 12.3 & -1.6 & -0.4 & 0.5 & -0.4 & -13.8 & -4.4 \\
\hline \multicolumn{9}{|l|}{ International trade } \\
\hline Exports & 180.2 & 7.3 & 18.9 & 1.6 & 0.4 & -0.6 & -32.6 & -22.0 \\
\hline Imports & 157.1 & -7.6 & -18.6 & -2.9 & 0.3 & -1.4 & 5.7 & -2.3 \\
\hline Per capita consumption of fish & 37.1 & 13.4 & -1.4 & 1.6 & 0.6 & -0.4 & -14.4 & -4.4 \\
\hline Consumer prices & 208.5 & -5.5 & -10.4 & -1.2 & -0.2 & -0.1 & 14.9 & 6.8 \\
\hline Producer prices & 191.9 & -4.4 & -7.7 & -1.1 & -0.2 & -0.1 & 13.1 & 6.2 \\
\hline \multicolumn{9}{|l|}{ Potential nutrient supply from fish } \\
\hline Vitamin A & 22.9 & 8.9 & 0.3 & 4.6 & 0.5 & 0.0 & -18.8 & -10.8 \\
\hline Iron & 1.3 & 11.8 & 1.6 & 2.4 & 0.8 & 0.0 & -15.7 & -6.3 \\
\hline lodine & 16.2 & 9.9 & 3.6 & 1.5 & 0.4 & -0.3 & -15.9 & -6.3 \\
\hline Zinc & 1.1 & 8.4 & -1.9 & 1.9 & 0.0 & -0.9 & -15.9 & -8.4 \\
\hline Calcium & 226.6 & 3.2 & 1.6 & 4.2 & 0.5 & -0.3 & -18.8 & -13.5 \\
\hline
\end{tabular}




\begin{tabular}{lrrrrrrrr} 
Protein & 14.2 & 14.1 & -0.5 & 1.6 & 0.6 & -0.4 & -14.8 & -4.4 \\
Energy & 371.6 & 16.6 & 6.3 & 1.3 & 0.4 & 0.3 & -16.0 & -3.0 \\
Fresh fish used as fishmeal inputs & 774.5 & -1.2 & -11.1 & -19.9 & 0.1 & -0.9 & 0.2 & 0.6 \\
\hline
\end{tabular}




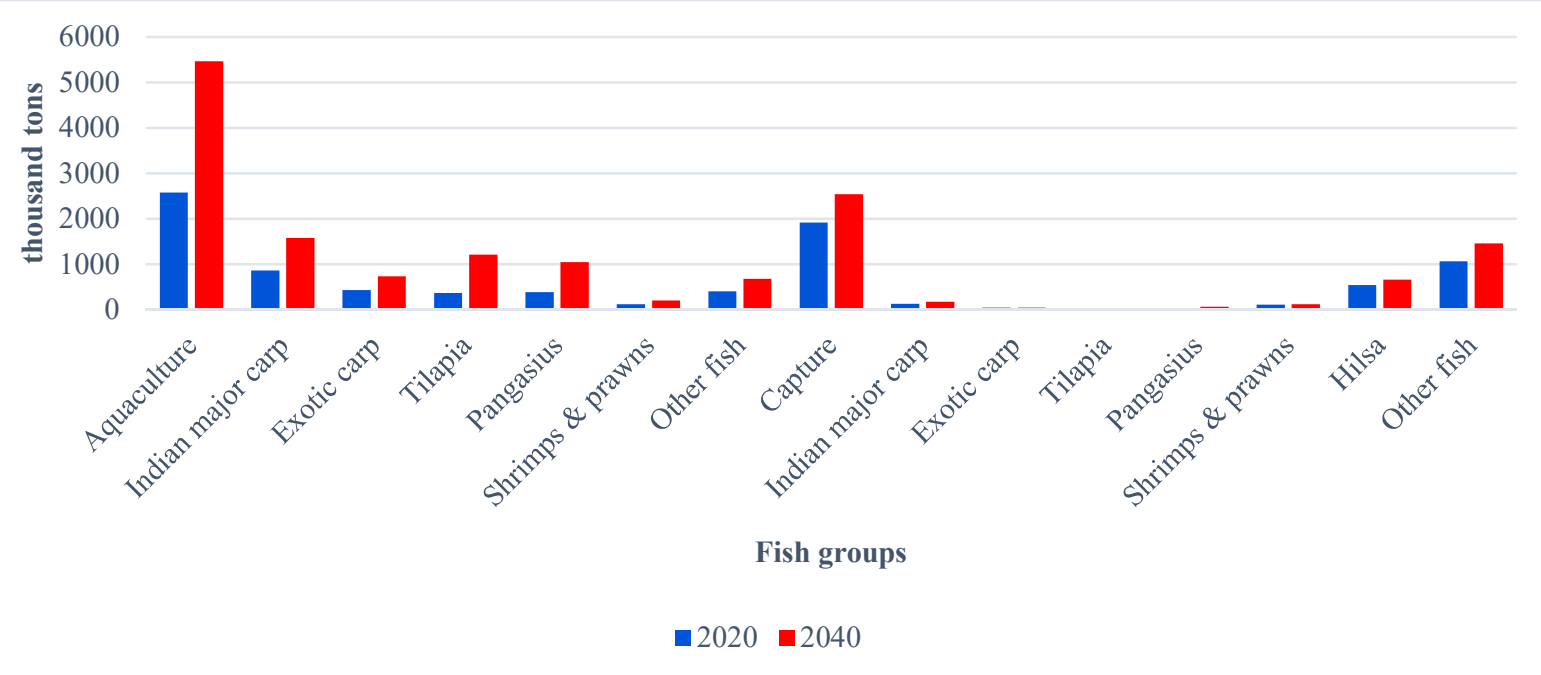

Fig. 1. Projection aquaculture and capture fisheries production in the BAU scenario by fish groups

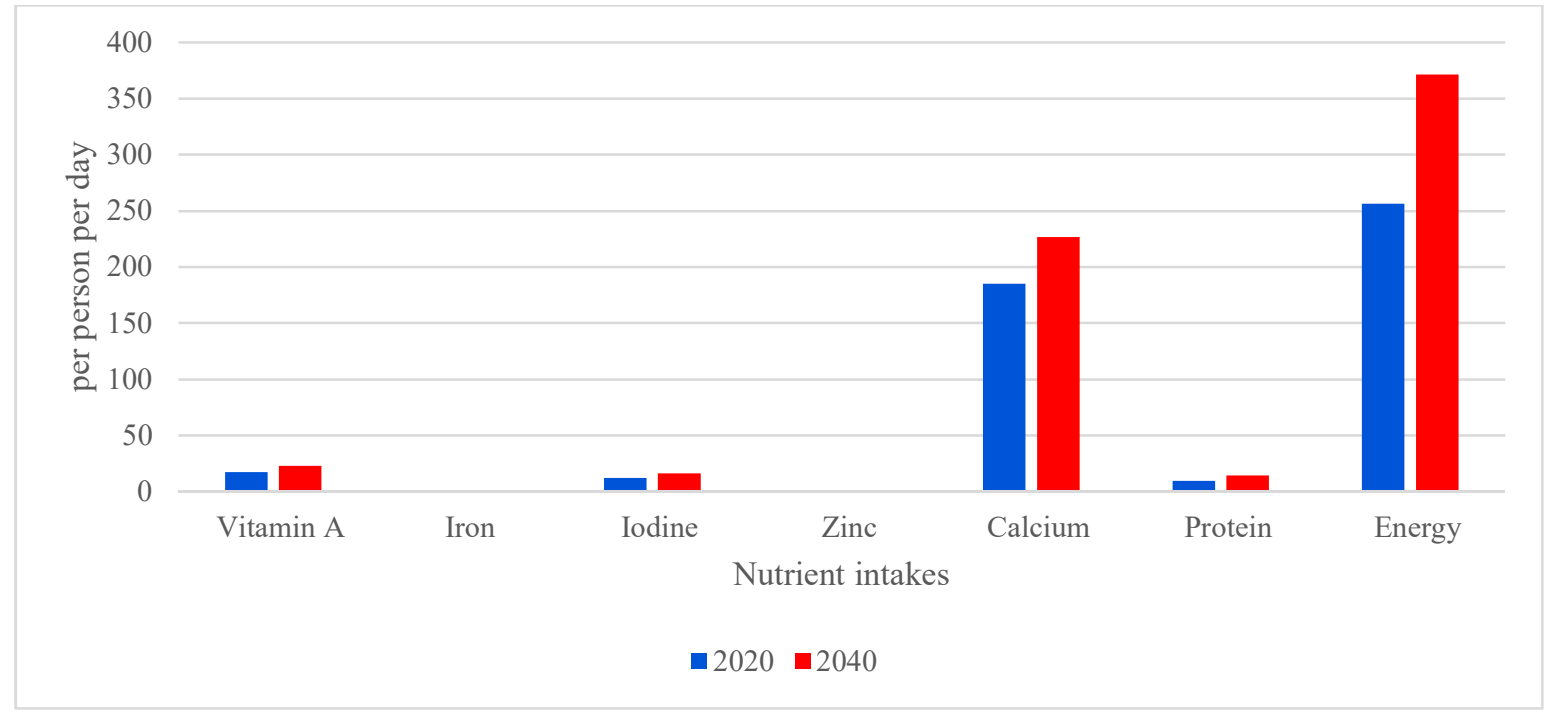

Fig. 2. Projection of nutrient intakes from fish in the BAU scenario 


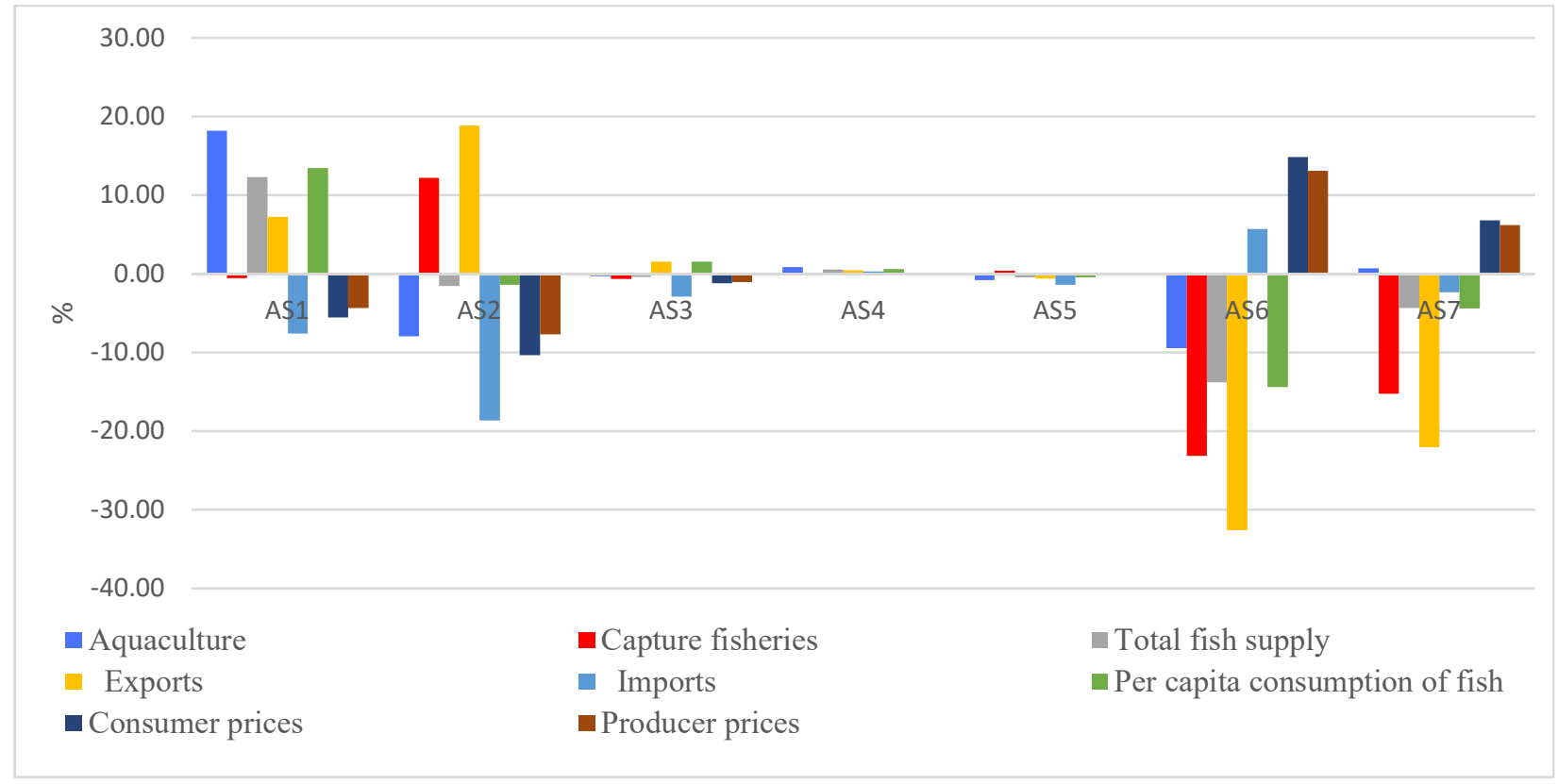

Fig. 3. The percentage deviation from the BAU scenario in 2040 on fish supply, demand, trade and prices

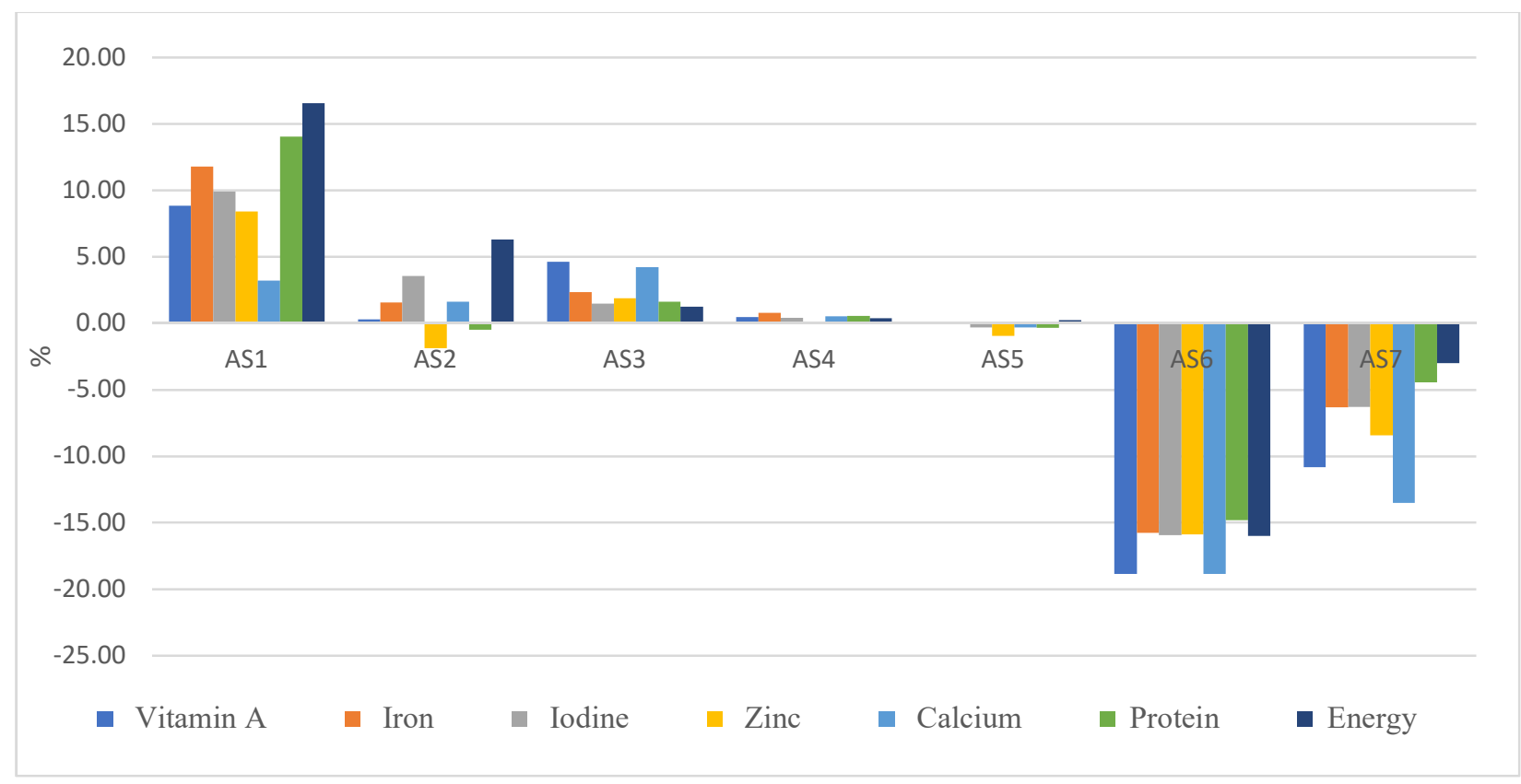

Fig. 4. The percentage deviation from the BAU scenario in 2040 on the nutrient intakes from fish 


\section{Discussion and policy implications}

Fisheries and aquaculture are integral parts of agri-food systems, playing an important role in supplying affordable and more environmentally sustainable fish and other aquatic foods to meet the national objective of ensuring food and nutrition security and also supporting sustainable livelihoods and socio-economic development in Bangladesh and many other developing countries. Early recognition and understanding of critical drivers and challenges influencing the sectors are essential for policy and decision-makers to formulate and guide the sectors' development strategies, policies, plans and interventions to support food and nutrition security and other sustainable development goals. Our results provide some insights into the prospects and challenges of future fish supply, demand, trade, prices and key nutrient sources from fish in Bangladesh under various future scenarios to 2040 .

Based on historical trends, the BAU scenario projects the outcome of Bangladesh's fisheries and aquaculture sector development until 2040. In this scenario, fish supply and demand in Bangladesh is projected to grow over time, and the country will remain a net fish exporter by 2040. While the growth of capture fisheries would slow down, as observed in other studies (Tran et al., 2017; Islam, 2018), aquaculture development is projected to be strong, and aquaculture will be the major source of future fish supply in Bangladesh to 2040. On the demand side, fish consumption will continue to increase, primarily driven by rapid population growth, higher income, urbanisation, diet shift due to increased recognition of health and nutritional benefits of fish consumption. The fast-increasing demand from domestic consumers would shrink the net trade surplus, though Bangladesh would remain a (net) fish exporter. Our BAU scenario highlights the importance of 
accelerating sustainable aquaculture growth and sustaining capture fisheries for contributing to food and nutrition security, one of the most pressing policy priorities in Bangladesh.

Our alternative scenarios investigate the impacts of possible changes deterring from the historical trends factored in the BAU scenario. Considered changes include variations in hilsa capture fisheries productivity (AS2), the impacts of disease outbreaks and climate change (AS5, AS6), and possible stagnancy of capture fisheries (AS7). These adverse impacts would slow down the growth of fish supply, resulting in a lower per-capita consumption level. Interventions favourable to capture fisheries production, which are captured by AS2, tend to generate similar outcomes, particularly fish exports. Increases in capture fisheries output as demonstrated in AS2 do not necessarily translate into higher total fish production because the induced decline in aquaculture production may overcome the gains in capture fisheries output. We also analyse the positive outcomes of public and private investments and interventions to accelerate aquaculture of farmed tilapia, pangasius, and IMC (mainly rohu carp) (AS1) and improvements in feed quality and price (AS3, AS4). If successfully realised, these interventions would make fish products more affordable by lowering prices, increasing fish consumption, and net export.

Our analysis also shows that changes in the fishery sector would directly impact the nutrient supply for Bangladesh people. Climate change and the stagnancy of capture fisheries would have far-reaching effects on nutrient supply from fisheries products. Since capture fisheries are a significant source of essential micronutrients for many poor and vulnerable consumers, declines in capture fisheries would increase the fish price, jeopardising the key nutrient contributions from fish to Bangladeshis population. Thus, it 
is essential to promote the sustainable development of the capture fisheries and reduce the vulnerability to climate risks via various community-based strategies and adaptations such as integrated coastal zone management, institutional support, technical assistance, and strong collaboration among the key stakeholders (Ahmed and Diana, 2015).

Our results highlight the need to support sustainable aquaculture growth to enhance the fishery sector contribution to food and nutrition security in Bangladesh. Proaquaculture policies and interventions can be implemented to improve fish farming productivity and promote technological progress to reduce the price of feed - the key aquaculture input, to increase the profitability of fish farmers. In addition, policies should be developed to encourage development and adoption of nutrition-sensitive aquaculture approaches, embracing the diversity of commercially farmed-fish species with nutrient rich small and indigenous species to provide higher nutritional quality and accessibility of fish among the households who are poor and undernourished.

Nutrition-sensitive aquaculture can play a crucial role in improving nutrition and health. A successful example is the Mola Promotion Program along with other small indigenous species in carp polyculture, a cost-effective and higher-health-benefit program (Fielder et al., 2016). This example shows that homestead pond polyculture, a mix of micronutrient-rich mola and other small indigenous fish species and carp 'cash-crop' species and integrated production system in lowland alternate to rice (rice-fish) using community-based fisheries and aquaculture approaches, can be implemented to generate long-term impact on the micronutrient deficiencies to healthy diet. Polyculture carp with small and indigenous species plays a critical role to combat the malnutrition as this approach can provide regular fish production for households' consumptions, in 
addition to increasing accessibility of fish among poor and vulnerable household groups to ensure the nutrient availability from fish (Worldfish, 2020).

\section{Conclusion}

We applied the AsiaFish model to generate fish supply and demand projections and draw insights for development plans and food policies in Bangladesh. We find both challenges (e.g., the impacts of climate change, infectious diseases in aquaculture, and stagnancy of capture fisheries) and opportunities (fast-growing demand driven by demographic and population growth, possible improvements in productivity and efficiency) for the fishery sector. Our results can be utilised as a preliminary input for new policy responses to challenges and opportunities.

Our analysis shows that the aquaculture sector would play an increasingly important role in the fishery sector. It is an important policy priority to support sustainable aquaculture growth to enhance the fishery sector contribution to food and nutrition security. Investments in "nutrition-sensitive" aquaculture approaches can be considered an approach to tackling malnutrition and food insecurity. Furthermore, investments in improving and sustaining the capture fisheries is critical to ensure capture fisheries continue to be a major solution to tackle the malnutrition and food insecurity in Bangladesh. While our analysis is undertaken for the fishery sector of Bangladesh, we contend that its implications may apply to other developing countries facing similar policy challenges and development objectives. 


\section{Acknowledgement}

This work was undertaken as part of the CGIAR Research Program on Fish AgriFood Systems (FISH) led by WorldFish. Funding support to the study was provided by the German Federal Ministry for Economic Cooperation and Development (BMZ) through the Deutsche Gesellschaft für Internationale Zusammenarbeit (GIZ), on a project entitled "Aquaculture and the Poor: Improving Fish Production, Consumption and Nutrition Linkages", the CGIAR Research Program on Policies, Institutions and Markets (PIM) and the CGIAR Research Program on Fish Agri-food Systems (FISH). We gratefully acknowledge the logistics and technical support from WorldFish Bangladesh. The views expressed in this document cannot be taken to reflect the official opinions of these organizations.

\section{Conflict of interest}

The authors declare that they have no known competing financial interests or personal relationships that could have appeared to influence the work reported in this paper.

\section{References}

Ahmed, N., Diana, J., 2015. Threatening "white gold": Impacts of climate change on shrimp farming in coastal Bangladesh, Ocea. Coast. Manage. 114: 42-52

Ahmed, N., Hossain, M., Humayun, N., Haque, M., Talukder, R., 2004. Final Country Report: Bangladesh. ADB-RETA Project on Strategies and Options for Increasing 
and Sustaining Fisheries and Aquaculture Production to Benefit the Poor Household in Asia, report submitted to the WorldFish Center, Penang, May.

Armington, P., 1969. A theory of demand for products distinguished by place of production, IMF Staff Papers. 16(1): 159-176.

Asian Development Bank., 2020. Key Indicators for Asia and the Pacific 2020. Accessed on September 2021 from < https://kidb.adb.org/>.

Asian Development Bank., 2014. Key Indicators for Asia and the Pacific 2014. Accessed on August 2015 from < http://www.adb.org/adbi/main >.

Bangladesh Bureau of Statistics (BBS)., 2020. Consumer Price Index (CPI), Inflation Rate and Wage Rate Index in Bangladesh. BBS, Ministry of Planning, Dhaka, December.

Bangladesh Bureau of Statistics (BBS)., 2018. Consumer Price Index (CPI), Inflation Rate and Wage Rate Index in Bangladesh. BBS, Ministry of Planning, Dhaka, December.

Bangladesh Bureau of Statistics (BBS)., 2017. Statistical yearbook of Bangladesh. Bangladesh: Bangladesh bureau of statistics, Government of Bangladesh.

Bangladesh Bureau of Statistics (BBS)., 2015. Consumer Price Index (CPI), Inflation Rate and Wage Rate Index in Bangladesh. BBS, Ministry of Planning, Dhaka, December. 
Bangladesh Bureau of Statistics (BBS)., 2013. 2012_Statistical Yearbook of Bangladesh. $32^{\text {nd }}$ edition, BBS, Ministry of Planning, Dhaka, August.

Banks, J., Blundell, R., Lewbel, A., 1997. Quadratic engel curves and consumer demand. The Rev. Econ. Stat. 85(2), 298-306.

Belton, B., Ahmed, N., Murshed-e-Jahan, K., 2014. Aquaculture, employment, poverty, food security and well-being in Bangladesh: A comparative study. Penang, Malaysia: CGIAR Research Program on Aquatic Agricultural Systems Program Report: AAS- 2014-39.

Belton, B., Thilsted, S.H., 2014. Fisheries in transition: Food and nutrition security implications for the global South. Glob. Food Secu. 3 (2014)59-66. http://dx.doi.org/10.1016/j.gfs.2013.10.0 01

Bene, C., Arthur, R., Norbury, H., Allison, E., Beveridge, M., Bush, S., Campling, L., Leschen, W., Little, D., Squires, D., Thilstead, S., Troell, M., Williams, M., 2016. Contribution of fisheries and aquaculture to food security and poverty reduction: Assessing the current evidence, World Dev. 79: 177-196.

Blundell, R., Pashardes, P., Weber, G., 1993. American economic association what do we learn about consumer demand patterns from micro data ? Am. Econ. Rev. 83(3) 570-597. https://www.jstor.org/stable/2117534.

Bogard, J. R., Farook, S., Marks, G.C., Waid, J., Belton, B., Ali, M., Toufique, K., Mamum, A., Thilsted, S.H., 2017. Higher fish but lower micronutrient intakes: Temporal changes in fish consumption from capture fisheries and aquaculture in 
Bangladesh. PLoS ONE 12(4): e0175098. https://doi.org/10.1371/journal. pone.0175098

Bogard, J.R., Marks, G.C., Mamun, A., Thilsted, S.H., 2016. Non-farmed fish contribute to greater micronutrient intakes than farmed fish: results from an intra-household survey in rural Bangladesh. Public Health Nutr. 2016:1-10.

Bogard, J., Thilsted, S., Marks, G., Wahab, M. A., Hossain, M., Jakobsen, J., Stangoulis, H., 2015. Nutrient composition of important fish species in Bangladesh and potential contribution to recommended nutrient intakes, J. Food Com. Analy. 2015: 120-133.

Brooks, A. and M. Philips. 2012. Fish supply and demand in the Lower Mekong Basic with special reference to Cambodia. SRA Final Report, Australian Center for International Agricultural Research (ACIAR), Canberra, Australia.

Chan, C.Y., Tran, N., Pethiyagoda, S., Crissma, C. C., Sulser, T. B., Phillips, M. J., 2019. Prospects and challenges of fish for food security in Africa. Glob. Food. Secu. 20. https://doi.org/10.1016/i.gfs.2018.12.002

Chan, C.Y., Tran, N., Dao, C.D., Sulser, T. B., Phillips, M. J., Batka, M., Wiebe, K. D., Preston, N., 2017. Fish to 2050 in the ASEAN region. Penang, Malaysia: Worldfish and Washington DC. International Food Policy Research Institute (IFPRI), USA (Working Paper: 2017-01). 
Chand, B., Trivedi, R., Dubey, S., Rout, S., Beg, M., Das, U., 2015. Effect of salinity on survival and growth of giant freshwater prawn Macrobrachium rosenbergii (de Man), Aqua. Reports. 2: 26-33.

Chang, C.Y., Witzke, H. P., Latka, C., 2018. A model for data consolidation of the fish market in Capri. In: Proceedings of the 58th Annual Conference on German Association of Agricultural Economists (GEWISOLA), Kiel, Germany, September 12-14, 2018. http://ageconsearch.umn.edu/record/276013/files/2191. pdf

Delgado, C.L., Wada, N., Rosegrant, M. W., Meijer, S., Ahmed, M., 2003. Fish to 2020: Supply and demand in changing global markets. WorldFish Center Technical Report. International Food Policy Research Institute, Washington, DC, pp. 62.

Department of Fisheries, 2017. Fisheries statistical yearbook of Bangladesh 2015-2016. Fisheries Resources Survey System, Department of Fisheries, Bangladesh.

Dey, M.M., Rosegrant, M. W., Gosh, K., Chen, O. L., Valmonte-Santos, R., 2016. Analysis of the economic impact of climate change and climate change adaptation strategies for fisheries sector in Pacific coral triangle countries: model, estimation strategy, and baseline results. Mari. Poli. 67:156-163.

Dey, M. M., Briones, R., Ahmed, M., 2005. Projecting supply, demand and trade for specific fish types in Asia: baseline model and estimation strategy. Aqua. Econ. Manag. 9: 113-39. 
Edgerton, D., 1997. Weak separability and the estimation of elasticities in multistage demand systems, Am. J. Agric. Econ. 79 (1997) 62-79. http://dx.doi.org/10.2307/ 1243943.

Ezzati, M, Riboli, E., 2013. Behavioural and dietary risk factors for noncommunicable diseases. N Engl J Med. 2013; 369(10):954-64. https://doi.org/10.1056/NEJMra1203528 PMID: 24004122

FAO, 2020. Fishery and aquaculture statistics. global fisheries commodities production and trade 1976-2018 (FishstatJ). In: FAO Fisheries Division [online]. Rome. Updated 2020. Accessed on September 2021 from < www.fao.org/fishery/statistics/software/fishstatj/en">

FAO, 2016. The state of world fisheries and aquaculture - Contributing to food security and nutrition for all. Rome

FAO, 2014. FAO Statistical Database (Fish Stat J). Version 1.1.1, Released 30 January 2014. Accessed on September 2015 from < http://www.fao.org/fishery/statistics/software/fishstatj/ en>.

Fiedler, J., Lividini, K., Drummond, E., Thilsted, S., 2016. Strengthening the contribution of aquaculture to food and nutrition security: The potential of vitamin A-rich, small fish in Bangladesh, Aquaculture. 452: 291-303

Fiedler, J.L., Lividini, K., Bermudez, O.I., 2014. Estimating the impact of vitamin A-fortified vegetable oil in Bangladesh in the absence of dietary assessment data. Public Health Nutr. 18 (3), 414-420. http://dx.doi.org/10.1017/S1368980014000640. 
Finegold, C., 2009. The importance of fisheries and aquaculture to development. Fisheries, Sustainability and Development, 353-364.

FRSS., 2020. Fisheries statistical yearbook of Bangladesh: 2018-2019. Bangladesh: Fisheries Resources Survey System (FRSS), Department of Fisheries, 2018.

FRSS., 2018. Fisheries statistical yearbook of Bangladesh: 2016-2017. Bangladesh: Fisheries Resources Survey System (FRSS), Department of Fisheries, 2018.

Garcia, Y., Piadozo, E., Rodriguez, U., Paris, T., Ramirez, P., 2013. Effects of trade reforms on Philippine agriculture and fishery. Ch. 6 in F. Lantican, C. Aragon and colleagues, Challenges and Agenda for Action for the Philippine Agriculture Sector. University of the Philippines Los Baños (UPLB), Southeast Asian Regional Center for Graduate Study and Research in Agriculture (SEARCA) and Philippine Council for Agriculture Aquatic and Natural Resources (PCAARRD), Laguna, Philippines, pp. 215-258.

Hallstrom, E., Bergman, K., Mifflin, K., Parker, R., Tyedmers, P., Troell, M., Ziegler F., 2019. Combined climate and nutritional performance of seafoods. J Clean Prod. 230: 402-411. doi:10.1016/j.jclepro.2019.04.229

Harika, R., Samuel, F., Kimiywe, J. 2017. Are low intakes and deficiencies in Iron, Vitamin A, Zinc, and lodine of public health concern in Ethiopian, Kenyan, Nigerian, and South African children and adolescents? Food Nutri. Bulle.38(3) 405-427. 
Henriksson, P., Tran, N., Mohan, C., Chan, C. Y., Rodriguez, U., Mateos, L., Utomo, N., Priyo, N., Hall, S., Phillips, M., 2017. Indonesian Aquaculture Futures - Evaluating environmental and socioeconomic potentials and limitations, J Clean Prod. 162: $1482-1490$.

Islam, M. M., Shamsuddoha, Md., 2018. Coastal and marine conservation strategy for Bangladesh in the context of achieving blue growth and sustainable development goals (SDGs). Environ. Sci. Policy. 45-54. https://doi.org/10.1016/j.envsci.2018.05.014

Latka, C., Heckelei, T., Batka, M., Boere, E., Chang, C. Y., Cui, D., Geleijnse, M., Havlik, P., Kuijsten, A., Kuiper, M., Leip, A., van't Veer, P., Witzke, H. P., Ziegler, F., 2018. SUSFANS Project H2020/SFS-19 - 2014: Sustainable food and nutrition security through evidence-based EU agro-food policy GA no. 633692. The potential role of producer and consumer food policies in the EU to Sustainable Food and Nutrition Security (Deliverable No. 10.3). http://edepot.wur.nl/464089〉

Mojid, M. A. 2020. Climate change-induced challenges to sustainable development in Bangladesh. IOP Conference series: Earth Environ. Sci.423 012001

Nestel, P., Clifton, P., Colquhoun, D., Noakes, M., Mori, T.A., Sullivan, D., 2015. Indications for omega-3 long chain polyunsaturated fatty acid in the prevention and treatment of cardiovascular disease. Heart Lung Circ. 2015; 24(8):769-79. https://doi.org/10.1016/j.hlc.2015.03.020 PMID: 25936871 
National Institute of Population Research and Training (NIPORT), Mitra and Associates, and ICF International., 2016. Bangladesh Demographic and Health Survey 2014. Dhaka, Bangladesh, and Rockville, Maryland, USA: NIPORT, Mitra and Associates, and ICF International.

OECD/FAO., 2017. Fish in seafood. In: OECD-FAO Agricultural Outlook 2017-2026. OECD Publishing, Paris. https://doi.org/10.1787/agr outlook-2017-12-en.

Phillips, M., Henriksson, P., Tran, N., Chan, C. Y., Mohan, C., Rodriguez, U., Suri, S., Hall, S., 2015. Exploring Indonesian Aquaculture Futures. WorldFish Program Report 2015-39, WorldFish Center, Penang, Malaysia.

Rashid, S., Zhang, X., 2019. The making of a blue revolution in Bangladesh: enablers, impacts, and the path ahead for aquaculture. Washington, DC: International Food Policy Research Institute. https://doi.org/10.2499/9780896293618.

Rodriguez U., P. Ramirez, S. Esguerra and L. Garces., 2019. Impacts of Fisheries Management and Policy Scenarios in Saranggani and Sulu-Sulawesi Seas to Philippine Tuna Industry: Simulations from the AsiaFish Model. J. Econ. Manag. Agric. Dev. 5(1): 9-22, June

Rodriguez, U., Ramirez, P., Zamora, G., Perez, M., Phillips, M., 2018. Future scenarios for the supply and demand of fish in the Philippines: Simulations from the AsiaFish model. Philippine Agricultural Scientist, 101(4): 392-407.

Rodriguez, U., Pulis, A., Gordon, A., 2011. Scenarios for the fisheries sector of Ghana: An application of the AsiaFish model. Annex C in A. Gordon and A. Pulis, The 
Consumption of Low Value Food Fish in Sub-Saharan Africa: Evidence from Ghana, Uganda and Senegal, WorldFish Center, Penang, Malaysia, September.

Rosegrant, M.W., Sulser, T.B., Mason-D’Croz, D., Cenacchi, N., Nin-Pratt, A., Dunston, S., Zhu, T., Ringler, C., Wiebe, K., Robinson, S.,Willenbockel, D., Xie, H., Kwon, H. Y., Johnson, T., Thomas, T. S., Wimmer, F., Schaldach, R., Nelson, G. C., Willaarts, B., 2017. Quantitative foresight modeling to Inform the CGIAR Research Portfolio. International Food Policy Research Institute (IFPRI), Washington DC, USA. http:// www.ifpri.org/publication/foresight-modeling-agricultural-research

Rosegrant, M.W., Team, I.D., 2012. International Model for Policy Analysis of Agricultural Commodities and Trade (IMPACT): Model Description. International Food Policy Research Institute (IFPRI), Washington, DC.

Tacon, A.G.J., Metian, M., 2013. Fish matters: importance of aquatic foods in human nutrition and global food supply. Rev. Fish. Sci. 21 (1), 22-38.

Tran, N., Cao, Q.L., Shikuku, K.M., Phan, T.P.,Banks, L.K., 2020. Profitability and perceived resilience benefits of integrated shrimp-tilapia-seaweed aquaculture in North Central Coast, Vietnam. Mari. Policy, $120 \quad(2020) 104153$. https://doi.org/10.1016/j.marpol.2020.104153

Tran, N., Chu, L., Chan, C. Y., Genschick, S., Phillips, M. J., Kefi, A. S., 2019. Fish supply and demand for food security in Sub-Saharan Africa: An analysis of the Zambian fish sector. Mari. Policy, 99:343-350. https://doi.org/10.1016/j.marpol.2018.11.009 
Tran, N., Rodriguez, U. P., Chan, C. Y., Phillips, M. J., Mohan, C. V., Henriksson, P. J. G., Koeshendrajana, S., Suri, S., Hall, S., 2017. Indonesian aquaculture futures: An analysis of fish supply and demand in Indonesia to 2030 and role of aquaculture using the AsiaFish model. Mari. Policy, 79:25-32. https://doi.org/10.1016/j.marpol.2017.02.002

United Nations., 2014. World Statistics Pocketbook 2014 Edition. Series V, No. 38, Statistics Division, Department of Economic and Social Affairs, United Nations, New York.

Weeratunge, N., Pemsl, D., Rodriguez, U., Chen, O., Badjeck, M., Schwarz, A., Paul, C., Prange, J., Kelling, I., 2010. Planning for the Use of Fish for Food Security in Solomon Islands. Research report submitted by the WorldFish Center to the World Wildlife Fund, Penang, Malaysia, May.

Willett, W., Rockstrom J., Loken B., Springmann M., Lang T., Vermeulen S., Garnett T., Tilman D., DeClerck F., Wood A., 2019. Food in the anthropocene: the EATLancet commission on healthy diets from sustain- able food systems. Lancet. 393(10170):447-492. doi:10. 1016/S0140-6736(18)31788-4

World Bank, 2021. World development Indicators. Last updated 30 June 2021. Accessed on July 2021 from www.worldbank.org.>.

World Bank, 2013. Fish to 2030: Prospects for Fisheries and Aquaculture. World Bank, Washington D. C. 
Worldfish, 2020. CGIAR research program on fish agri-food systems. Annual report 2019. https://digitalarchive.worldfishcenter.org/bitstream/handle/20.500.12348/4230/d4c cf7a63539764ae57dc3f67310b885.pdf 
Annex 1 Nutrition data from Bogard et al. (2016) and its classification in the AsiaFish model

\begin{tabular}{|c|c|c|c|c|c|c|c|c|}
\hline \multirow{3}{*}{$\begin{array}{c}\text { Fish group } \\
\text { Bogard et al. } \\
(2016)\end{array}$} & \multicolumn{8}{|c|}{ Nutrient } \\
\hline & AsiaFish & Vitamin & Iron ${ }^{b}$ & Zinc $^{b}$ & lodine $^{b}$ & Energyc & Protein ${ }^{d}$ & Edible \\
\hline & model & $A^{a}$ & & & & & & portione \\
\hline \multicolumn{9}{|l|}{ Common } \\
\hline Carp & Exotic carp & na & 11 & 22 & 130 & 3,810 & 164 & na \\
\hline Grass Carp & Exotic carp & na & 5 & 9 & na & 3,410 & 152 & 0.82 \\
\hline Silver Carp & Exotic carp & na & 44 & 14 & na & 4,350 & 172 & 0.81 \\
\hline \multicolumn{9}{|l|}{ Thai } \\
\hline Sharpunti & Exotic carp & 120 & 16 & 18 & 380 & 4,660 & 184 & 0.80 \\
\hline Ilish & Hilsa & 200 & 19 & 12 & 370 & 10,200 & 164 & 0.87 \\
\hline \multirow[t]{2}{*}{ Jatka llish } & Hilsa & 140 & 25 & 18 & 340 & 6,180 & 190 & na \\
\hline & Indian & & & & & & & \\
\hline \multirow[t]{2}{*}{ Catla } & major carp & 220 & 8 & 11 & 180 & 2,670 & 149 & 0.79 \\
\hline & Indian & & & & & & & \\
\hline \multirow[t]{2}{*}{ Mrigal } & major carp & 150 & 25 & 15 & 150 & 3,630 & 189 & 0.77 \\
\hline & Indian & & & & & & & \\
\hline Rui & major carp & 130 & 10 & 10 & 200 & 4,220 & 182 & 0.79 \\
\hline
\end{tabular}


Boro

\begin{tabular}{|c|c|c|c|c|c|c|c|c|}
\hline Kholisha & Other fish & 460 & 41 & 23 & 200 & 3,810 & 179 & na \\
\hline Maita & Other fish & na & 5 & 7 & 140 & 2,920 & 166 & \\
\hline Koi & Other fish & 2950 & 9 & 6 & na & 3,540 & 152 & 0.86 \\
\hline Mola & Other fish & 25030 & 57 & 32 & 170 & 4,000 & 155 & .82 \\
\hline \multicolumn{9}{|l|}{ Mola } \\
\hline (cultured) & Other fish & 22260 & 190 & 42 & 330 & 3,850 & 155 & .82 \\
\hline Baim & Other fish & 270 & 19 & 11 & 130 & 3,490 & 152 & .7 \\
\hline Bele, Bailla & Other fish & 180 & 23 & 21 & 250 & 3,840 & 155 & 0.5 \\
\hline Chanda & Other fish & 3360 & 21 & 26 & 240 & 3,870 & 147 & 0.9 \\
\hline Chapila & Other fish & 730 & 76 & 21 & 130 & 3,600 & 179 & .8 \\
\hline Chela & Other fish & 1320 & 8 & 47 & 190 & 3,840 & 205 & 0.80 \\
\hline Darkina & Other fish & 6600 & 120 & 40 & 810 & 4,790 & 168 & 0.83 \\
\hline Dhela & Other fish & 9180 & 18 & 37 & 95 & 3,940 & 179 & $0 . c$ \\
\hline Ekthute & Other fish & 980 & 15 & 36 & 110 & 4,310 & 172 & \\
\hline Foli & Other fish & na & 17 & 16 & na & 5,410 & 157 & $c$ \\
\hline Golsha & Other fish & na & 18 & 13 & 130 & 2,670 & 119 & 0.8 \\
\hline
\end{tabular}




\begin{tabular}{|c|c|c|c|c|c|c|c|c|}
\hline Guchi & Other fish & 780 & 27 & 13 & 190 & 7,510 & 171 & na \\
\hline Gutum & Other fish & 760 & 33 & 25 & 160 & 3,290 & 171 & 0.86 \\
\hline Jat Punti & Other fish & 540 & 22 & 29 & 200 & 7,370 & 155 & 0.92 \\
\hline Kachki & Other fish & 780 & 28 & 31 & 60 & 3,300 & 169 & 1.00 \\
\hline \multicolumn{9}{|l|}{ Kajuli, } \\
\hline Bashpata & Other fish & 370 & 8 & 12 & 71 & 3,260 & 165 & 0.86 \\
\hline Kakila & Other fish & 910 & 7 & 19 & 370 & 3,380 & 167 & 0.67 \\
\hline \multicolumn{9}{|l|}{ Kuli, Bhut } \\
\hline Bailla & Other fish & 370 & 8 & 20 & 310 & 6,190 & 162 & na \\
\hline Magur & Other fish & 250 & 12 & 7 & 220 & 4,450 & 173 & 0.87 \\
\hline Meni, Bheda & Other fish & 600 & 8 & 16 & 130 & 4,120 & 147 & 0.71 \\
\hline \multicolumn{9}{|l|}{ Modhu } \\
\hline Pabda & Other fish & na & 5 & 9 & 70 & 6,540 & 149 & 0.79 \\
\hline Rani, Bou & Other fish & 240 & 25 & 40 & 250 & 3,740 & 191 & 0.76 \\
\hline Shing & Other fish & 320 & 22 & 11 & na & 3,060 & 183 & 0.78 \\
\hline Taki & Other fish & 1390 & 18 & 15 & 180 & 3,870 & 172 & 0.87 \\
\hline Tara Baim & Other fish & 830 & 25 & 12 & 130 & 4,280 & 151 & 1.01 \\
\hline Tengra & Other fish & 120 & 40 & 31 & 280 & 3,850 & 154 & 0.89 \\
\hline
\end{tabular}




\begin{tabular}{|c|c|c|c|c|c|c|c|c|}
\hline Tit Punti & Other fish & 210 & 34 & 38 & 190 & 2,860 & 171 & 0.64 \\
\hline Gojar & Other fish & na & 4 & 6 & 140 & 3,100 & 187 & na \\
\hline Shol & Other fish & na & 4 & 7 & na & 3,200 & 172 & 0.89 \\
\hline Foli Chanda & Other fish & na & 3 & 7 & 94 & 3,570 & 176 & na \\
\hline Kata Phasa & Other fish & na & 16 & 31 & 100 & 3,810 & 181 & 0.85 \\
\hline Lal Poa & Other fish & na & 17 & 21 & 410 & 4,050 & 205 & na \\
\hline Murbaila & Other fish & na & 17 & 8 & 190 & 3,100 & 188 & na \\
\hline Parse & Other fish & na & 13 & 8 & 69 & 8,130 & 161 & 0.84 \\
\hline Tailla & Other fish & na & 6 & 9 & 260 & 4,250 & 206 & na \\
\hline Tular Dandi & Other fish & na & 21 & 9 & 200 & 3,450 & 193 & na \\
\hline Thai Pangas & Pangas & 310 & 7 & 7 & na & 9,250 & 160 & 0.80 \\
\hline \multicolumn{9}{|l|}{ Majhari Thai } \\
\hline Pangas & Pangas & 120 & 27 & 11 & 170 & 3,600 & 186 & na \\
\hline Harina & Shrimps \& & & & & & & & \\
\hline \multirow[t]{2}{*}{ Chingri } & prawns & na & 27 & 13 & 260 & 3,330 & 176 & 0.40 \\
\hline & Shrimps \& & & & & & & & \\
\hline Najari Icha & prawns & na & 130 & 33 & 1,200 & 3,640 & 157 & na \\
\hline Tilapia & Tilapia & 100 & 11 & 12 & 110 & 3,900 & 195 & 0.80 \\
\hline
\end{tabular}


Majhari

Tilapia

Tilapia

210

16

14

na $\quad 4,120$

190

na

Notes: ${ }^{a}$ in micrograms $/ \mathrm{kg}$ of edible parts; ${ }^{\mathrm{b}}$ in milligrams $/ \mathrm{kg}$ of edible parts; ${ }^{\mathrm{c}}$ in kilojoules/kg of edible parts; ${ }^{d}$ in grams $/ \mathrm{kg}$ of edible parts; ${ }^{\text {e }} 0.79$ means that $79 \%$ of fish parts are edible. 